\title{
COMPARATIVE HISTOLOGICAL EVALUATION OF THE FRUIT OF RIBES NIGRUM AND RIBES RUBRUM
}

\author{
Eszter LACZKÓ-ZÖLD ${ }^{1}$, Andrea KOMLÓSI ${ }^{2}$, Erzsébet VARGA $^{1 *}$, Nóra PAPP ${ }^{2}$ \\ ${ }^{1}$ Department of Pharmacognosy and Phytotherapy, George Emil Palade University of Medicine, Pharmacy, \\ Sciences and Technology of Targu Mures, Gh. Marinescu 38, 540139 Targu Mures, Romania \\ ${ }^{2}$ Department of Pharmacognosy, University of Pécs, Rókus 2, 7624 Pécs, Hungary
}

*Correspondence:
Erzsébet VARGA
erzsebet.varga@umfst.ro

Received: 04 December 2019; Accepted: 12 December 2019; Published: 30 December 2019

\begin{abstract}
To complete the wide range of studies on chemical composition and pharmacological potential of the fruit of Ribes nigrum and Ribes rubrum, this work aimed to perform a comparative morpho-anatomical characterization of the fruits of both species and complete previously records of black currant as frequently studied species. Microslides of fruits were made with rotation microtome, and then cross sections were stained with toluidine blue. Documentation and evaluation were carried out in microphotos. In $R$. rubrum, the epidermis cells are ovoid to round, while those of $R$. nigrum are rectangular to almost round. Under the epidermis, in both fruits, there are two layers of oval hypodermal cells. Underneath the hypodermal layers, parenchyma cells of different size with thin walls and scattered collateral closed bundles were detected. The seeds are embedded in a gelatinous sheath having large thin-walled cells. Endocarp separates the arillar tissue from parenchyma cells, in addition, a gap can be found among these layers, endocarp, arillar tissue, and seeds. The seed coat consists of sclerenchyma cells in both species. In conclusion, histological differences and similarities were described in the fruits of the selected Ribes species, highlighted the first morpho-anatomical description of the berry of Ribes rubrum.
\end{abstract}

Keywords: Ribes nigrum, Ribes rubrum, fruit, microscopic examination.

\section{Introduction}

Grossulariaceae family is composed of approximately 195 species (The Plant List, 2018). According to Plant Database (USDA, 2018) there are 65 species of Ribes genus including native and introduced plants in the USA. In Europe 16 Ribes species are known (Marhold, 2011; EU-NOMEN) involving 8 taxa in Romania namely $R$. uva-crispa L., $R$. nigrum L., $R$. alpinum L., $R$. aureum Pursh, $R$. sanguineum Pursh, $R$. petraeum Wulfen in Jacq., R. spicatum Robson, and R. rubrum L.
(Ciocarlan, 2000). Ribes nigrum (black currant) is a perennial shrub which grows in bushy places, groves (Ciocarlan, 2000). It is also widely cultivated for berry production. The species has a wide variety of secondary metabolites. Leaves contain lignoids (Sasaki et al. 2013), glycosides of quercetin and kaempferol as major phenolics (Liu et al., 2014), accompanied by significant amounts of salicylic acid, p-coumaric acid, caffeic and gallic acids (Nour et al., 2014). Mineral and 
trace elements also were measured in the leaves of different cultivars of the plant (Nour et al., 2014). Fruits contain phenolics: they are especially rich in anthocyanins, e.g. glycosides of delphinidin and cyanidin (Gavrilova et al. 2011). The level of anthocyanins varies depending on the season, degree of maturity, environmental conditions, type of cultivation, and genetic characters (Milivojevic et al., 2012; Zheng et al., 2012; Vagiri et al., 2013; MikulicPetkovsek et al., 2015). Among organic acids, citric, fumaric and malic acids are dominant (Mikulic-Petkovsek et al., 2012; Woznicki et al., 2017). The fruits are rich in vitamin C (Häkkinen et al. 1999).

Ribes rubrum (red currant) is cultivated in Romania, which is not the member of the spontaneous flora (Ciocarlan, 2000). In the literature it is known under synonymies $R$. vulgare Lam. and $R$. sylvestre Mert. et Koch (Ciocarlan, 2000; Marhold, 2011; EUNOMEN). In phytochemical aspect, anthocyanin content - mostly glycosides of cyanidin (Gavrilova et al., 2011; MikulicPetkovsek et al., 2015) - is about $10 \%$ in the fruit compared to that of black currant (Gavrilova et al., 2011; Mikulic-Petkovsek et al., 2015). Among flavonoids, glycosides of quercetin, myricetin and kaempferol (MikulicPetkovsek et al. 2015), as well as citric, fumaric and malic acids were detected in the plant in similar, but shikimic acid in 13 times higher quantity compared to the fruit of black currant (Mikulic-Petkovsek et al. 2012).

In the fruit of both species, fructose and glucose are predominant among sugars (Mikulic-Petkovsek et al., 2012; Woznicki et al., 2017). The seed oil is rich in tocopherol, unsaturated fatty acids, linoleic, $\alpha$-linolenic, and $\gamma$-linolenic acids (Traitler et al., 1984; Goffman and Galetti, 2001; Leskinen et al., 2009; Vuorinen et al., 2016).

In pharmacological aspect, currants were studied for the effect in dietary management of various diseases (Zágoni, 2005; Zdunić et al., 2016). Polyphenolic substances of the fruit and leaf were earlier examined for the antiinflammatory, antioxidant, antifungal, and anticancer effect (Knekt et al., 1997; Šavikin et al., 2009; Bishayee et al., 2010; Slavin and Lloyd, 2012). The polyphenolic composition of the fruit and the leaf of black currant plays a role in the structure of biological and lipid membranes, highlighted flavonols in the leaf, and anthocyanins in the fruit as dominant antioxidant compounds. The studied extracts protected the membranes against the oxidation and modified the properties of the hydrophilic regions of the membranes (Cyboran et al. 2014). The fruits of black and red currant were tested in vitro for potential management of type 2 diabetes and hypertension resulted high $\alpha-$ glucosidase, $\alpha$-amylase and ACE inhibitor activities in red currant (Da Silva Pinto et al., 2010).

Despite the described phytochemical and pharmacological potential of the selected species, there are few studies on the morphoanatomical description of the fruits as medicinally used parts in Ribes species (Wrońska-Pilarek, 2001; Wrońska-Pilarek, 2002; Kendir et al., 2015). In an earlier report arrilar tissue was observed in several species of the genus. Among them, arils cover the seeds in the slightly fleshy pericarps in $R$. nigrum, which is absent in $R$. rubrum (Corner, 1976).

In the last two decades, only one histological report was published on the fruit of black currant (Glidewell et al., 1999), and according to our best knowledge no other recent study is available concerning the histology of red currant. Thus, this work aimed to perform a comparative histological characterization of the fruit of $R$. nigrum and $R$. rubrum collected in Romania. 


\section{Materials and Methods}

\subsection{Plant material}

Fruits of $R$. nigrum and $R$. rubrum (10 pieces of each species) were harvested at full maturity from a local farmer's garden in July and August 2016 (Cornești, Mureș County, Romania). Collected samples were frozen and stored at $-20^{\circ} \mathrm{C}$ until analyses.

\subsection{Morphological and anatomical study}

For microscopic examination, whole fruits were preserved in the mixture of ethanol : glycerine : distilled water (1:1:1). Fruits were dehydrated in 50\%, 70\% and 96\% ethanol (Békési-Kallenberger et al. 2016), then they were embedded in Technovit ${ }^{\circledR} 7100$ resin (Realtrade Ltd., Hungary). $15 \mu \mathrm{m}$ thick crosssections were obtained with a rotary microtome (Anglia Scientific 0325) (Papp et al., 2013). The slides were dried at $50^{\circ} \mathrm{C}$ for 2 hours, stained in toluidine blue $(0.02 \%)$ for $5 \mathrm{~min}$, and soaked twice in $96 \%$ ethanol (3 min each), isopropanol (4 min), and twice in xylol (3 and 4 min). Sections were studied with a NIKON Eclipse 80i microscope and micrographs were taken with SPOT Basic 4.0 image analysis system.

\section{Results and discussions}

\subsection{Histological features of the fruit of}

\section{Ribes nigrum}

In the fruit of $R$. nigrum, the epidermis is formed of rectangular to almost round shape cells covered by cuticle layer. Under the epidermis (epicarp), two layers of oval hypodermal cells can be found (Fig. 1 A,B). Under the hypodermal layers the mesocarp parenchyma is composed of different size of thin-walled cells and scattered vascular bundles (Fig. 1 A,C). The collateral closed vascular bundles consists of xylem and phloem that are surrounded by sclerenchyma (Fig. 1 D). Seeds are embedded in a gelatinous sheath which is constructed from large thin-walled cells (Fig. 2
A,B,C), accordingly to a previous study (Glidewell et al. 1999). The arillar tissue is separated from the endocarp by a space (Fig. 2 B). The seed coat (testa) consists of sclerenchyma cells (Fig. 2 D).

\subsection{Histological features of the fruit of Ribes rubrum}

In $R$. rubrum, the epidermis of the fruit is formed from more ovoid to round cells than those of $R$. nigrum. The double-layered hypodermis contains horizontally thick-walled and elongated cells (Fig. 3 A, 3 D). Parenchyma is composed of thin-walled cells in various sizes. The scattered collateral closed vascular bundles (Fig. 3 A) have only xylem and phloem elements (Fig. 3 B). Endocarp separates the arillar tissue from parenchyma cells; between arillar tissue and seeds a gap was observed (Fig. 3 C). Similar to black currant, seeds are embedded in a gelatinous sheath (Fig. 3 C, Fig. 4 A) consisting of large cells with slightly sinuous cell walls (Fig. 4 C). The seed coat includes sclerenchyma cells (Fig. 4 B), while the storage ground tissue consists of thick-walled cells in the seed (Fig. 4 D).

Under histological aspect, the stem of some Ribes species were described in wood anatomical atlases (Metcalfe and Chalk, 1957; Schweingruber et al. 2011), e.g. a diffuseporous xylem in Ribes nigrum (Schweingruber et al. 2011). In another work, the whole fruit of Ribes nigrum was analysed in different developmental stages (Glidewell et al. 1999). Morphological and histological characters of the seed were reported for native species like $R$. uva-crispa, R. alpinum, R. petraeum, and $R$. spicatum in Poland (Wrońska-Pilarek, 2001; Wrońska-Pilarek, 2002), as well as a surface analysis by scanning microscope on the fruit, seed and pollen of $R$. biebersteinii Berl. ex. DC, R. uva-crispa, R. alpinum, R. orientale Desf., $R$. multiflorum Kit. ex Romer \&Schultes, and $R$. anatolica Behçet which are native to 
Turkey (Kendir et al., 2015), without detailed histological description of all parts of the fruits. Based on these studies, our work describes the histological features of the whole fruit of Ribes nigrum and $R$. rubrum including the seeds from the collected samples from Romania. In this work the fruit of red currant is described in all details here for the first time. Similarities and differences were observed in microscopic preparations of the fruit of both currant species. Among similar features, a thin layer of cuticle, lack of stomata, two layers of hypodermal cells (Fig. 1 B, 2 A), scattered collateral closed bundles (Fig. 1 D, 3 B), and arillar tissue (Fig. 2 B) can be mentioned. The seed coats of both species consist of sclerenchyma cells surrounded by a gelatinous sheath (Fig. 1 C, 2 C) which is in accordance with earlier literature data (Glidewell et al. 1999). This sheath, also called sarcotesta, is different in thickness in Ribes species. Sometimes it is equal to the width of the seeds (Wrońska-Pilarek, 2001), but it is less than half of those in R. nigrum and $R$. rubrum described in this study. In both fruits, major part of the pericarp and the placental region is occupied by medium and large parenchyma cells (Fig. 1 A,C and Fig. 3 A,C,D), as it was previously described in black currant (Glidewell et al. 1999).

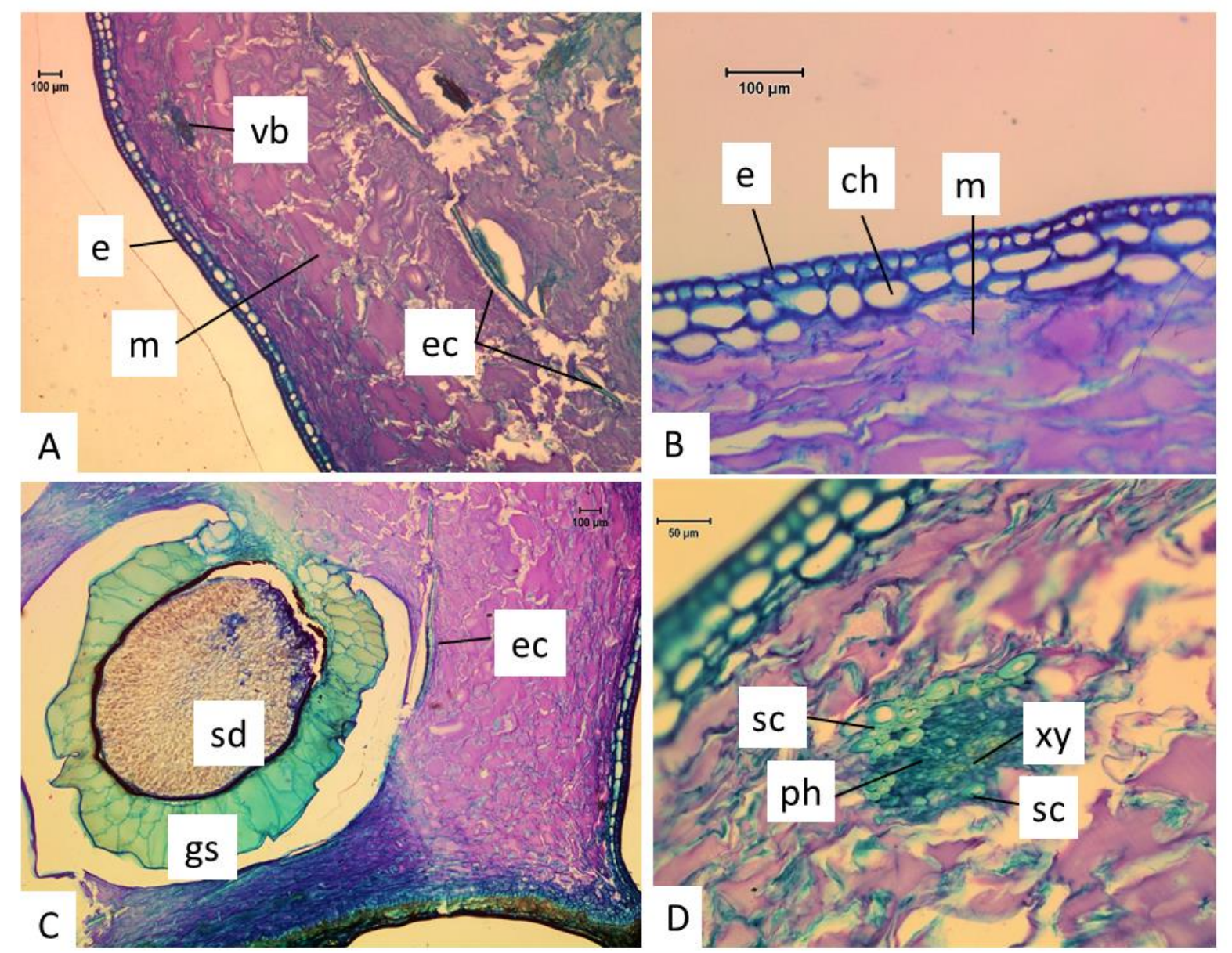

Fig. 1. Histological features of the fruit of Ribes nigrum. A-B) fruit wall; C) seed embedded in gelatinous sheath; D) collateral closed vascular bundle; e: epicarp (epidermis), ec: endocarp, ch: collenchymatic hypodermis, gs: gelatinous sheath, m: mesocarp, xy: xylem, ph: phloem, sc: sclerenchyma, sd: seed, vb: vascular bundle 


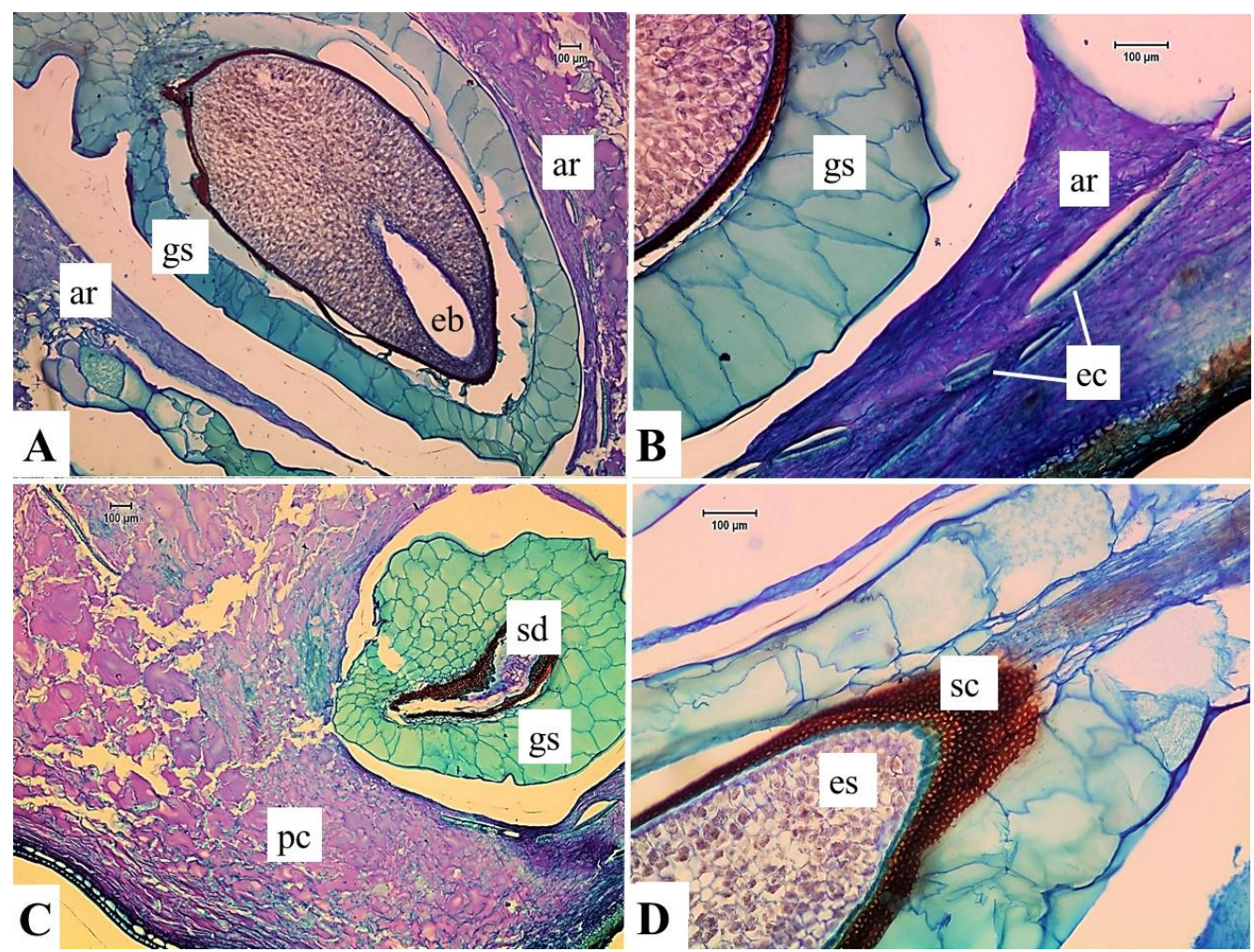

Fig. 2. Histological features of the seed of Ribes nigrum. A) seed; B) aril; C) gelatinous cells; D) testa; ar: aril, eb: the place of embryo (tissue is missing), ec: endocarp, es: endosperm, gs: gelatinous sheath, pc: parenchyma cells, sc: sclerenchyma cells, sd: seed
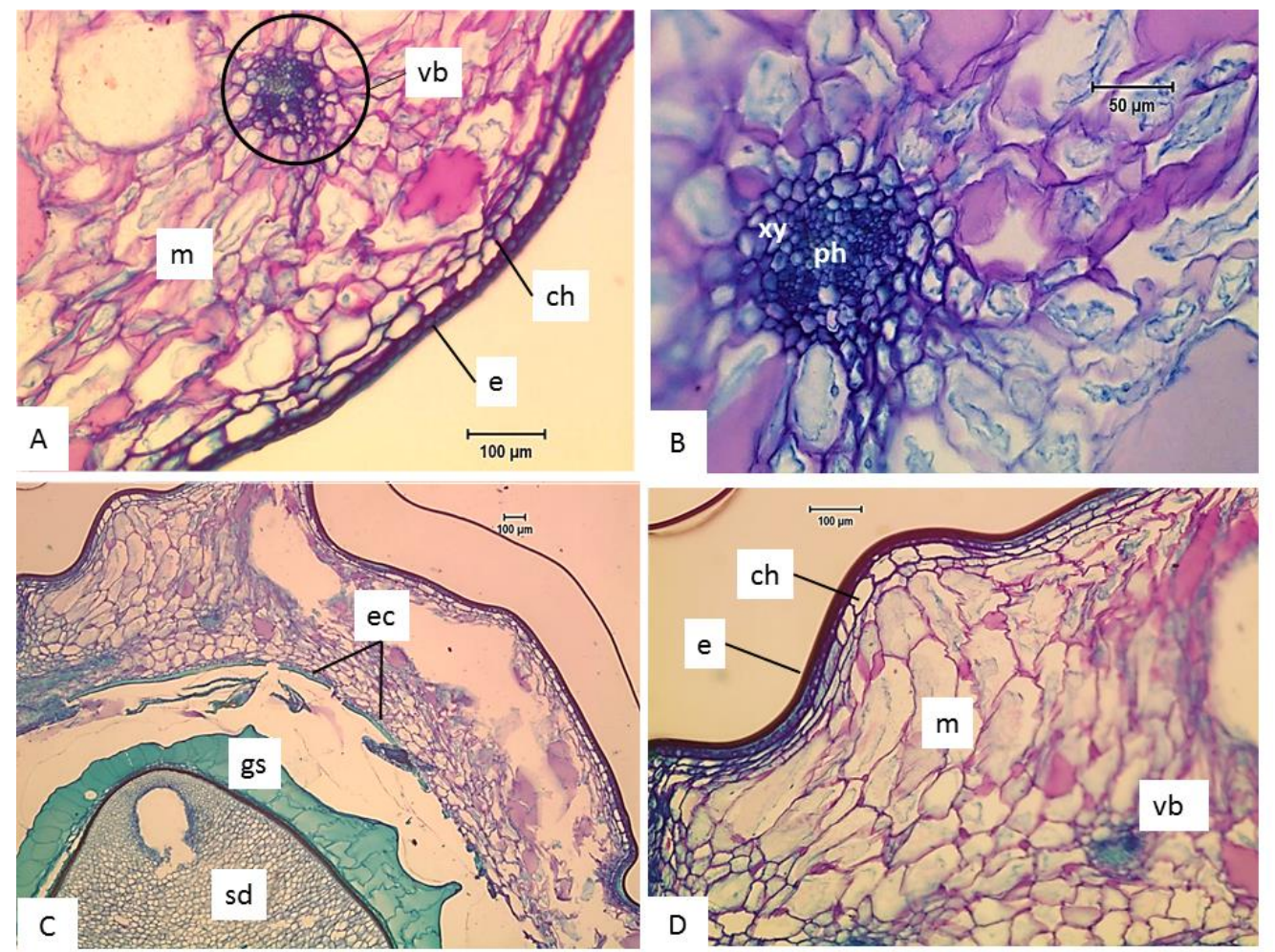

Fig. 3. Histological features of the fruit of Ribes rubrum. A) pericarp; B) vascular bundle; C) seed embedded in gelatinous sheath; D) pericarp; e: epicarp (epidermis), ec: endocarp, ch: collenchymatic hypodermis, gs: gelatinous sheath, m: mesocarp, xy: xylem, ph: phloem, sd: seed, vb: vascular bundle 
As differences, various shapes of epidermis cells (Fig. 1 B, 3 A) and different intensity of dyeing of parenchymal cells were observed: stronger coloration of the pericarp and placenta refer to a higher polysaccharide content in black currant compared to red currant (Fig. 1 A, 3 A,C). Contrary to gooseberry's fruit (Williamson et al., 1993), the gelatinous sheath around the seeds is not single-layered, but multi-layered up to six cell layers in the studied species (Fig. 1 C, 4 A). In the endosperm, fatty oil drops were detected in $R$. nigrum (Fig. 2 D), which does not appear in $R$. rubrum (Fig. 4 D). This is in accordance with earlier findings using Sudan IV: coloration was found only in the external layer of the endosperm in red currant (WrońskaPilarek 2001).

Generally, in berries (Giongo et al. 2013), as in other fruits such as tomato (Saladie et al. 2007), the texture of the fruit is related to the cell wall structure and to change in ripening phases (Giongo et al. 2013). The structure of the pericarp has a great influence on the storage ability of the ripe fruit and the postharvest management. As expected, epidermal cells in the berry of black and red currant are covered by cuticle which can explain the relative long maintenance of their freshness.
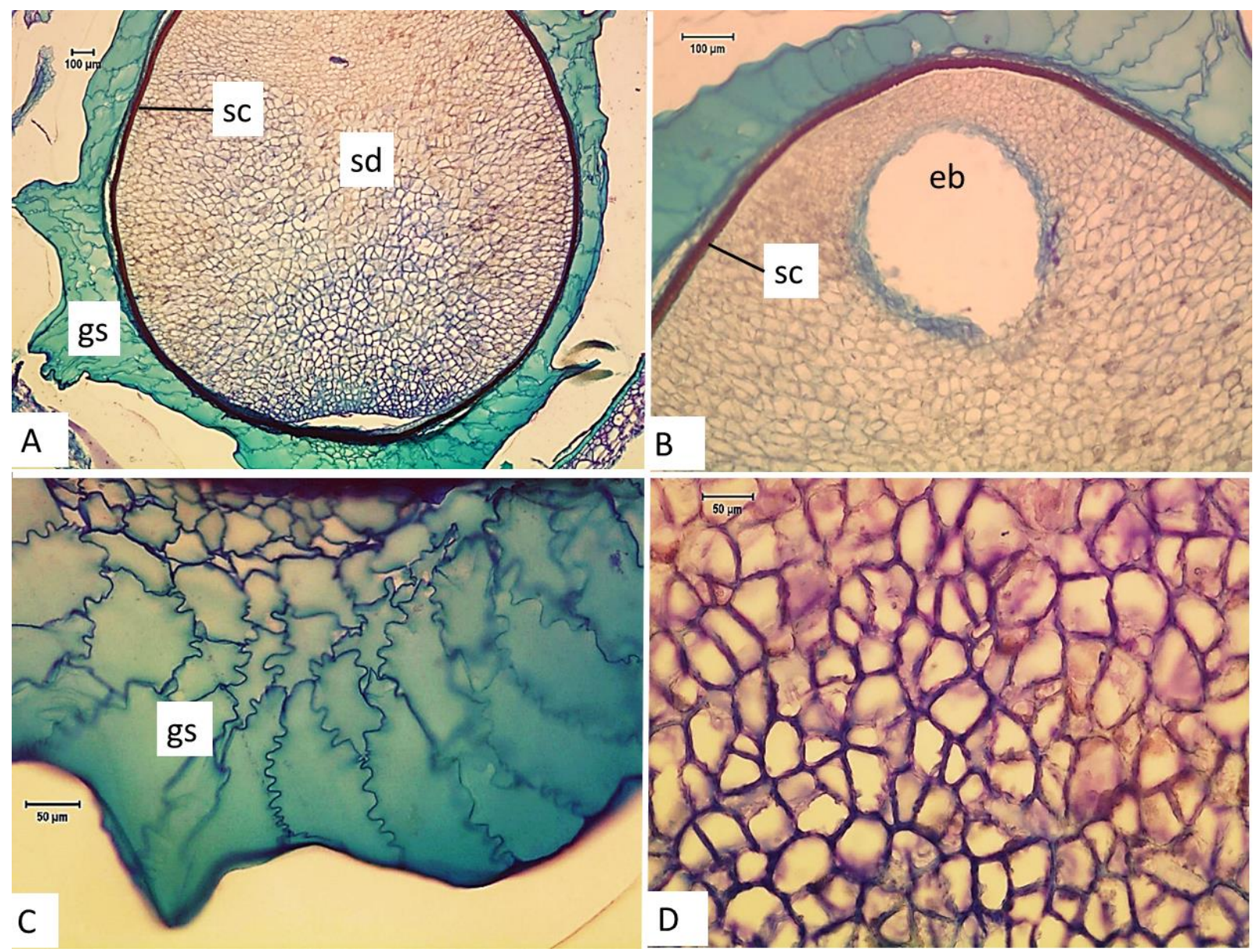

Fig. 4. Histological features of the seed of Ribes rubrum. A) Seed embedded in gelatinous sheath;

B) seed; C) gelatinous sheath; D) endosperm; eb: the place of embryo (tissue is missing), gs: gelatinous sheath, sc: sclerenchyma cells, sd: seed 


\section{Conclusions}

The histological determination of the fruit of Ribes nigrum and $R$. rubrum complete the reported data of the species. In the fruits of the selected Ribes species differences and similarities are described, which highlight the first morpho-anatomic study of the fruit of Ribes rubrum. The observed features play an important role in the characterisation, which will be useful providing a reliable basis for identification of the fruits.

\section{Conflict of Interest}

The authors declare that the research was conducted in the absence of any commercial or financial relationships that could be construed as a potential conflict of interest.

\section{Acknowledgments}

The study was supported by the Research Grant of the University of Pécs (PTE ÁOK KA-2017-27), grant from OTKA (K 127944), and the Research Grant of Studium Prospero Foundation (0350/26.02.2016)

\section{References}

1. Békési-Kallenberger $\mathrm{H}$, Horváth GY, Bencsik T, Balázs Vl, Filep R, Papp N (2016) Comparative Histological and Phytochemical Study of Fallopia species. Natural Product Communications 11:251254.

2. Bishayee A, Háznagy-Radnai E, Mbimba T, Sipos P, Morazzoni P, Darvesh AS, Bhatia D, Hohmann J (2010) Anthocyaninrich black currant extract suppresses the growth of human hepatocellular carcinoma cells. Natural Product Communications 5:1613-1618.

3. Ciocarlan V (2000) Flora ilustrată a României, Editura Ceres, Bucureşti

4. Corner EJH (1976) The seeds of dicotyledons. Cambridge University Press, Cambridge

5. Cyboran S, Bonarska-Kujawa D, Pruchnik H, Zyłka R, Oszmiański J, Kleszczyńska H (2014) Phenolic content and biological activity of extracts of black currant fruit and leaves. Food Research International 65:47-58. doi: 10.1016/j.foodres.2014.05.037.

6. Da Silva Pinto M, Kwon Yi, Apostolidis E, Lajolo FM, Genovese M, Shetty K (2010)
Evaluation of red currants (Ribes rubrum L.), black currants (Ribes nigrum L.), red and green gooseberries (Ribes uva-crispa) for potential management of type 2 diabetes and hypertension using in vitro models. Journal of Food Biochemistry 34:639-660. doi: 10.1111/j.1745-4514.2009.00305.x

7. EU-NOMEN (n.d.) http://www.eunomen.eu/portal/taxon.php?GUID= 3734D1D0-9A3C-41FC-BCB920279F1C1502 (accessed 18 sept. 2018).

8. Gavrilova V, Kajdžanoska M, Gjamovski V, Stefova M (2011) Separation, characterization and quantification of phenolic compounds in blueberries and red and black currants by HPLC-DAD-ESIMSn. Journal of Agricultural and Food Chemistry 59(8):4009-4018. doi: 10.1021/jf104565y

9. Giongo L, Poncetta P, Loretti P, Costa F (2013) Texture profiling of blueberries (Vaccinium spp.) during fruit development, ripening and storage. Postharvest Biology and Technology 76:34-39. doi: 10.1016/j.postharvbio.2012.09.004

10. Glidewell S, Williamson B, Duncan GH, Chudek J, Hunter G (1999) The 
development of black currant fruit from flower to maturity: A comparative study by 3D nuclear magnetic resonance (NMR) micro-imaging and conventional histology. New Phytologist 141(1):85-98. doi: 10.1046/j.1469-8137.1999.00319.x

11. Goffman F, Galetti S (2001) Gammalinolenic acid and tocopherol contents in the seed oil of 47 accessions from several Ribes species. Journal of Agricultural and Food Chemistry 49(1):349-354. doi: 10.1021/jf0006729

12. Häkkinen SH, Kärenlampi SO, Heinonen IM, Mykkänen HM, Törronen AR (1999) Content of the flavonols quercetin, myricetin, and kaempferol in 25 edible berries. Journal of Agricultural and Food Chemistry 47(6):2274-2279. doi: 10.1021/jf9811065

13. Kendir G, Güvenç A, Acar A, Çeter T, Pinar NM (2015) Fruits, seeds and pollen morphology of Turkish Ribes L. (Grossulariaceae). Plant Systematics and Evolution 301(1):185-199. doi: 10.1007/s00606-014-1064-2

14. Knekt P, Järvinen R, Seppänen R, Hellövaara M, Teppo L, Pukkala E, Aromaa A (1997) Dietary flavonoids and the risk of lung cancer and other malignant neoplasms. American Journal of Epidemiology 146(3):223-30. doi: 10.1093/oxfordjournals.aje.a009257

15. Leskinen H, Suomela, Kallio H (2009) Effect of latitude and weather conditions on the regioisomer compositions of $\alpha$ - and $\gamma$ linolenoyldilinoleoylglycerol in currant seed oils. Journal of Agricultural and Food Chemistry. 57(9):3920-3926. doi: 10.1021/jf900068b

16. Liu P, Kallio H, Yang B (2014) Flavonol glycosides and other phenolic compounds in buds and leaves of different varieties of black currant (Ribes nigrum L.) and changes during growing season. Food
Chemistry 160:180-189. doi: 10.1016/j.foodchem.2014.03.056

17. Marhold K (2011) Grossulariaceae. Euro+Med Plantbase.

http://ww2.bgbm.org/euroPlusMed/PTaxon Detail.asp?UUID=3734D1D0-9A3C-41FCBCB9-20279F1C1502 (accessed 18 september 2018).

18. Metcalfe CR, Chalk L (1957) Anatomy of the dicotyledons vol I., Oxford, At The Clarendon Press

19. Mikulic-Petkovsek M, Rescic J, Schmitzer V, Stampar F, Slatnar A, Koron D, Veberic $R$ (2015) Changes in fruit quality parameters of four Ribes species during ripening. Food Chemistry 173:363-374. doi: 10.1016/j.foodchem.2014.10.011

20. Mikulic-Petkovsek M, Schmitzer V, Slatnar A, Stampar F, Veberic R (2012) Composition of sugars, organic acids, and total phenolics in 25 wild or cultivated berry species. Journal of Food Science 77(10):1-7. doi: 10.1111/j.17503841.2012.02896.x

21. Milivojevic J, Slatnar A, MikulicPetkovsek M, Stampar F, Nikolic M, Veberic R (2012) The influence of early yield on the accumulation of major taste and health-related compounds in black and red currant cultivars (Ribes spp.). Journal of Agricultural and Food Chemistry 60(10):2682-2691. doi: $10.1021 /$ jf $204627 \mathrm{~m}$

22. Nour V, Trandafir I, Cosmulescu S (2014) Antioxidant capacity, phenolic compounds and minerals content of blackcurrant (Ribes nigrum L.) leaves as influenced by harvesting date and extraction method. Industrial Crops and Products 53:133-139. doi: 10.1016/j.indcrop.2013.12.022

23. Papp N, Csete S, Farkas Á (2013) Comparative ecomorphology of the cyathial nectaries in eight European Euphorbia 
species. Acta Biologica Hungarica 64(1):45-59. 10.1556/ABiol.64.2013.1.5

24. Saladie M, Matas AJ, Isaacson T, Jenks MA, Goodwin SM, Niklas KJ, Xiaolin R, Labavitch JM, Shackel KA, Fernie AR, Lytovchenko A, O'neill MA, Watkins CB, Rose JKC (2007) A reevaluation of the key factors that influence tomato fruit softening and integrity. Plant Physiology 144(2):1012-1028. doi: 10.1104/pp.107.097477

25. Sasaki T, Li W, Zaike S, Asada Y, Li Q, Ma F, Zhang Q, Koike K (2013) Antioxidant lignoids from leaves of Ribes nigrum. Phytochemistry 95:333-340. doi: 10.1016/j.phytochem.2013.07.022

26. Šavikin K, Zdunić G, Janković T, Tasić S, Menković N, Stević T, Đorđević B (2009) Phenolic content and radical scavenging capacity of berries and related jams from certificated area in Serbia. Plant Foods for Human Nutrition 64(3):212-217. doi: 10.1007/s11130-009-0123-2

27. Schweingruber FH, Börner A, Schulze ED (2011) Atlas of Stem Anatomy in Herbs, Shrubs and Trees vol 1, Springer-Verlag Berlin Heidelberg

28. Da Silva Pinto M, Kwon Y, Apostolidis E, Lajolo FM, Genovese MI, Shetty K (2010) Evaluation of red currants (Ribes Rubrum L.), black currants (Ribes Nigrum L.), red and green gooseberries (Ribes Uva-Crispa) for potential management of type 2 diabetes and hypertension using in vitro models. Journal of Food Biochemistry 34(3):639$660 . \quad$ doi: $\quad 10.1111 / \mathrm{j} .1745-$ 4514.2009.00305.x

29. Slavin JL, Lloyd B (2012) Health benefits of fruits and vegetables. Advances in nutrition (Bethesda, Md.) 3(4):506-16. doi: 10.3945/an.112.002154

30. The Plant List http://www.theplantlist.org/1.1/browse/A/G rossulariaceae/ (accessed 9.18.18).
31. Traitler H, Winter H, Richli U, Ingenbleek Y (1984) Characterization of gammalinolenic acid in Ribes seed. Lipids 19(12):923-928. doi: 10.1007/BF02534727

32. USDA. (n.d.). PlantsDatabase. https://plants.usda.gov/core/profile?symbol $=$ RIBES (accessed 9.18.18).

33. Vagiri M, Ekholm A, Öberg E, Johansson E, Andersson SC, Rumpunen K (2013) Phenols and ascorbic acid in black currants (Ribes nigrum L.): Variation due to genotype, location, and year. Journal of Agricultural and Food Chemistry 61(39):9298-9306. doi: 10.1021/jf402891s

34. Vuorinen Al, Kalpio M, Linderborg KM, Hoppula KB, Karhu ST, Yang B, Kallio HP (2016) Triacylglycerol biosynthesis in developing Ribes nigrum and Ribes rubrum seeds from gene expression to oil composition. Food Chemistry 196:976987. doi: 10.1016/j.foodchem.2015.10.010

35. Williamson B, Goodman BA, Chudek JA (1993) The structure of mature gooseberry (Ribes grossularia) fruits revealed noninvasively by NMR microscopy. Micron 24(4):377-383. doi: 10.1016/09684328(93)90003-J

36. Wojdylo A, Oszmianski O, Milczarek M, Wyetrzyk J (2013) Phenolic profile, antioxidant and antiproliferative activity of black and red currants (Ribes spp.) from organic and conventional cultivation. International Journal of Food Science and Technology 48:715-726. doi: 10.1111/ijfs. 12019

37. Woznicki Tl, Sønsteby A, Aaby K, Martinsen BK, Heide OM, Wold AB, Remberg SF (2017) Ascorbate pool, sugars and organic acids in black currant (Ribes nigrum L.) berries are strongly influenced by genotype and post-flowering temperature. Journal of the Science of Food and Agriculture 97(4):1302-1309. doi: 10.1002/jsfa. 7864 
38. Wrońska-Pilarek D (2002) Seed morphology of the native species of the genus Ribes L. Part 2. The characteristics of individual species. Acta Societatis Botanicorum Poloniae 71(1):5-16. doi: 10.5586/asbp.2002.001

39. Wrońska-Pilarek D (2001) Seed morphology of the polish native species of the genus Ribes L. Part 1. General characteristic. Acta Societatis Botanicorum Poloniae 70(4):281-289. doi: 10.5586/asbp.2001.036

40. Zágoni E (2005) A feketeribiszke. Alutus kiadó, Miercurea Ciuc

41. Zdunić G, Šavikin K, Pljevljakušić D, Djordjević B (2016) Black (Ribes nigrum L.) and red currant (Ribes rubrum L.) cultivars, in: Simmonds, M., Preedy, V. (Eds.), Nutritional Composition of Fruit Cultivars. Academic Press, pp. 101-106.

42. Zheng J, Yang B, Ruusunen V, Laaksonen O, Tahvonen R, Hellsten J, Kallio H (2012) Compositional differences of phenolic compounds between blackcurrant (Ribes nigrum L.) cultivars and their response to latitude and weather conditions. Journal of Agricultural and Food Chemistry 60(26):6581-6593. doi: 10.1021/jf3012739. 